Research Article

\title{
Histopathological spectrum of neoplastic and non-neoplastic breast lesions: A three years study in rural tertiary care center.
}

\author{
Dr Geeta Maurya ${ }^{1}$ Dr Sanjeev Kumar Singh ${ }^{2 *}$ Dr Pinki Pandey ${ }^{3}$ Dr Rashmi ${ }^{4}$ \\ ${ }^{1}$ Assistant Professor, Dept of Pathology, UPUMS, Saifai, Etawah \\ ${ }^{2}$ Associate Professor, Dept of Pathology, UPUMS, Saifai, Etawah \\ ${ }^{3}$ Professor \& Head, Dept of Pathology, UPUMS, Saifai, Etawah \\ ${ }^{4}$ Lecturer, Dept of Pathology, UPUMS, Saifai, Etawah
}

\begin{abstract}
-
Background: Breast tumours are very common cause of morbidity and mortality worldwide specially in developing countries. Breast lesions show broad spectrum of disease patterns in respect to benign, malignant, and non-neoplastic. Breast cancer is one of the most frequently occurring cancer among women.

Objective: To study the frequency, age distribution, clinical and histological patterns of neoplastic and nonneoplastic lesions of breast in this rural population.

Material and methods: This observational study was conducted over a duration of three years. In which we studied 210 cases of breast lesions. Specimens were received in department of pathology. Grossing, tissue processing, staining done according to standard protocol. Haematoxylin and eosin (H\&E) stained sections were examined under microscope to categorise different type of lesions in the form of non-neoplastic and neoplastic.
\end{abstract}

Results: Out of 210 breast lesions, fibroadenoma was the commonest (114 cases) benign lesion. While invasive ductal carcinoma (70 cases) was commonest in malignant category. Non neoplastic lesions stand on third place, study showed 6 cases out of 210 total cases, in which acute mastitis ( 4 cases) was most common. Benign tumours were mostly seen in $2^{\text {nd }}$ and $3^{\text {rd }}$ decade and malignant tumour mainly in $5^{\text {th }}$ and $6^{\text {th }}$ decade

Conclusion: Early histopathological diagnosis of breast lesions is very important to differentiate between benign and malignant lesions. Large number of cases of invasive ductal carcinoma (>33\% of all cases) were seen in our study, which is a serious concern. So, generation of awareness among women is need of time to reduce the morbidity and mortality specially in Indian rural setup.

Keywords: Benign breast lesion, malignant breast tumour, fibroadenoma, breast carcinoma

\section{Introduction:}

Most breast lesions found in women are benign e.g. fibroadenoma, fibrocystic change, breast abscess etc. Benign breast diseases are very common as compared to breast cancers and have broad limits of histological presentation. These variations create a challenge to the pathologist.

However, breast cancers are approximately $1 / 4^{\text {th }}$ of all malignant tumours, and among females $1 / 3^{\text {rd }}$ cancers are breast cancers. (1) Results of Breast cancer are very serious in respect of emotional disturbances and increased financial demand on patient. Benign tumours are 10 times more common than malignant tumours (2) Breast cancer related deaths are highly prevalent all over the world and has become a major health challenge. (3) 
Current study is histological and clinical study of breast lesions in northern rural India and the objective is to study the frequency of different type of breast lesions and its correlation with age, side of the breast involvement and most frequent quadrant involvement. We have categorized breast lesions into non neoplastic, neoplastic and neoplastic further divided into benign and malignant subdivision.

\section{Material and methods:}

This study was conducted in department of pathology, Uttar Pradesh University of Medical Sciences (UPUMS) Saifai Etawah. UPUMS Saifai is a tertiary health care centre of this rural region. Institutional ethical committee approved this study. Necessary informed consent from patients or their closed relatives had been taken. Duration of study was from January 2016 to December 2018.

This was a retrospective and prospective observational study. In this study we examined 210 cases of breast pathology, including all the mastectomies specimen and core needle biopsy specimen received in the department of pathology in the duration of study. We studied gross examination of all the cases. We also confirmed that sections from all the representative areas were taken and submitted to tissue processing. After processing paraffin blocks were prepared and tissue sections were cut and stained with haematoxylin and eosin ( $\mathrm{H} \& \mathrm{E})$ stain. Multiple (H\&E) sections were examined. Then we categorized different types of breast lesions after examining under the microscope.

\section{Results:}

In present study 210 cases of breast lesions during the period of 3 years (Jan 2016 to Dec 2018) were recorded. We diagnosed and categorized cases histologically and recorded each entity regarding age, sex and other clinical symptoms.

Histologically we divided lesions into neoplastic (benign and malignant) and non-neoplastic.

Out of 210 breast lesions $131(62.3 \%)$ were benign (including Fibroadenoma and benign breast lesions) and 73(34.7) were malignant and the ratio between two was $3.7: 1$. In benign breast disease, 128 specimens were of female and 3 were of male. Six (2.8\%) lesions were fall into non neoplastic category. (Table-1)

Benign lesions including fibroadenoma 114 (54.2\%) cases, tubular adenoma 2(0.9\%) cases, benign phyllodes $4(1.9 \%)$ cases, lipoma $2(0.9 \%)$ cases, fibroadenosis $1(0.4 \%)$ cases, gynecomastia3(1.4\%) cases, fibrocystic change $5(2.3 \%)$ cases. (Table-1)

Table-1- Frequency of breast lesions according to histopathological diagnosis

\begin{tabular}{|c|c|c|c|}
\hline $\begin{array}{l}\text { Broad } \\
\text { pathologica } \\
1 \text { categories } \\
\text { in this } \\
\text { study }\end{array}$ & $\begin{array}{l}\text { Histopathologi } \\
\text { cal diagnosis }\end{array}$ & $\begin{array}{l}\text { Numb } \\
\text { er of } \\
\text { cases }\end{array}$ & $\begin{array}{l}\text { Percenta } \\
\text { ge } \%\end{array}$ \\
\hline \multirow{7}{*}{$\begin{array}{l}\text { Benign } \\
\text { tumours } \\
\text { (Total } 131 \\
\text { cases) }\end{array}$} & Fibroadenoma & 114 & $54.28 \%$ \\
\hline & $\begin{array}{l}\text { Tubular } \\
\text { adenoma }\end{array}$ & 2 & $0.95 \%$ \\
\hline & $\begin{array}{l}\text { Benign } \\
\text { phyllodes } \\
\text { tumour }\end{array}$ & 4 & $1.90 \%$ \\
\hline & Lipoma & 2 & $0.95 \%$ \\
\hline & Fibroadenosis & 1 & $0.47 \%$ \\
\hline & $\begin{array}{l}\text { Fibrocystic } \\
\text { change }\end{array}$ & 5 & $2.38 \%$ \\
\hline & $\begin{array}{l}\text { Gynecomastia } \\
\text { (Male breast) }\end{array}$ & 3 & $1.42 \%$ \\
\hline \multirow{2}{*}{$\begin{array}{l}\text { Malignant } \\
\text { tumours } \\
\text { (Total } 73 \\
\text { cases) }\end{array}$} & $\begin{array}{l}\text { Invasive ductal } \\
\text { carcinoma } \\
\text { (NOS) }\end{array}$ & 70 & $33.33 \%$ \\
\hline & $\begin{array}{l}\text { Medullary } \\
\text { carcinoma }\end{array}$ & 3 & $1.42 \%$ \\
\hline \multirow{3}{*}{$\begin{array}{l}\text { Inflammato } \\
\text { ry lesions } \\
\text { (Total } 6 \\
\text { cases) }\end{array}$} & $\begin{array}{l}\text { Acute/chronic } \\
\text { mastitis }\end{array}$ & 4 & $1.90 \%$ \\
\hline & $\begin{array}{l}\text { Granulomatous } \\
\text { mastitis }\end{array}$ & 1 & $0.47 \%$ \\
\hline & Fat necrosis & 1 & $0.47 \%$ \\
\hline \multicolumn{2}{|l|}{ Total } & 210 & $100 \%$ \\
\hline
\end{tabular}

Malignant lesions including invasive ductal carcinoma $70(33.3 \%)$ cases and medullary carcinoma $3(1.4 \%)$ cases.

Non neoplastic breast lesions including acute mastitis $4(1.9 \%)$ cases, granulomatous mastitis 1 $(0.4 \%)$ cases, fat necrosis $1(0.4 \%)$ cases. 
Dr Geeta Maurya et./al Histopathological spectrum of neoplastic and non-neoplastic breast lesions: A three years study in rural tertiary care center

According to our study results most common benign lesion is fibroadenoma, most common malignant lesion is invasive ductal carcinoma and most common non neoplastic lesion is acute mastitis.

Breast lump followed by pain were the most common presenting complaints.

In our study age ranges from 13 to 80 years. Benign lesions were seen most commonly in $2^{\text {nd }}$ decade and malignant lesions were occurred in $5^{\text {th }}$ and $6^{\text {th }}$ decade. (Table-2)

Table-2-Age wise distribution Breast lesions

\begin{tabular}{|l|l|l|l|}
\hline $\begin{array}{l}\text { Age } \\
\text { range (in } \\
\text { years) }\end{array}$ & $\begin{array}{l}\text { Non- } \\
\text { neoplastic }\end{array}$ & \multicolumn{2}{|l|}{ Neoplastic } \\
\cline { 3 - 4 } & & $\begin{array}{l}\text { Benign } \\
\text { tumour }\end{array}$ & $\begin{array}{l}\text { Malignant } \\
\text { tumour }\end{array}$ \\
\hline $11-20$ & 1 & 71 & 0 \\
\hline $21-30$ & 3 & 43 & 3 \\
\hline $31-40$ & 1 & 9 & 23 \\
\hline $41-50$ & 0 & 7 & 23 \\
\hline $51-60$ & 1 & 1 & 14 \\
\hline $61-70$ & 0 & 0 & 8 \\
\hline $71-80$ & 0 & 0 & 2 \\
\hline Total & 6 & 131 & 73 \\
\hline
\end{tabular}

Involvement of left breast $112(53.3 \%)$ is more common than right breast $98(46.6 \%)$ is seen in our study.

In majority of cases lesion located in upper outer quadrant $85(40 \%)$ followed by upper inner quadrant $69(32.8 \%)$ and central part $56(26.6 \%)$ of the breast.

\section{Discussion:}

In our study total 210 cases were included in which 131 cases were benign and 73 cases were malignant. The ratio between benign and malignant lesions of breast is 3.7:1 which was almost double to the study done by Khanna et al (1998) and Pai S et al and almost similar to the study done by Sree ND et al. Kumar et al. Observed that developing countries have increased incidence of benign breast disease and its incidence is varies in different geographical areas. (4)(5)(6)(7)
According to our study benign diseases are more common as compared to malignant diseases, findings are similar to the studies done by Oluwle et al and Pai $\mathrm{S}$ et al. Fibroadenoma is commonest lesion 114(54.28\%) cases, this finding is comparable to the studies of Sree ND et al. (46.35\%), Amr et al(30.7\%), Kulkarni et al $(62.32 \%)$ and Malik et al (41\%). (8)(9)(10)(11)

Table-3- frequency distribution in different benign breast tumours (Comparison with other similar studies)

\begin{tabular}{|l|l|l|l|l|}
\hline $\begin{array}{l}\text { S1 } \\
\text { no }\end{array}$ & $\begin{array}{l}\text { Benign } \\
\text { tumours }\end{array}$ & $\begin{array}{l}\text { Mudholka } \\
\text { r et al al } \\
(2012)\end{array}$ & $\begin{array}{l}\text { Gaikwa } \\
\text { d SL et } \\
\text { al } \\
(2018)\end{array}$ & $\begin{array}{l}\text { This } \\
\text { study }\end{array}$ \\
\hline 1 & $\begin{array}{l}\text { Fibroadenom } \\
\text { a }\end{array}$ & $\begin{array}{l}111 \\
(87.40 \%)\end{array}$ & $\begin{array}{l}118 \\
(90 \%)\end{array}$ & $\begin{array}{l}114 \\
(87 \%)\end{array}$ \\
\hline 2 & $\begin{array}{l}\text { Benign } \\
\text { phyllodes } \\
\text { tumour }\end{array}$ & $8(6.29 \%)$ & $\begin{array}{l}6 \\
(4.58 \%)\end{array}$ & $\begin{array}{l}4 \\
(3 \%)\end{array}$ \\
\hline 3 & $\begin{array}{l}\text { Tubular } \\
\text { adenoma }\end{array}$ & $3(2.36 \%)$ & $\begin{array}{l}2 \\
(1.5 \%)\end{array}$ & $\begin{array}{l}2 \\
(1.5 \% \\
)\end{array}$ \\
\hline 4 & $\begin{array}{l}\text { Lactating } \\
\text { adenoma }\end{array}$ & - & $\begin{array}{l}2 \\
(1.5 \%)\end{array}$ & - \\
\hline 5 & $\begin{array}{l}\text { Lipoma } \\
\text { Tipoma }\end{array}$ & $\begin{array}{l}1 \\
(0.76 \%)\end{array}$ & $\begin{array}{l}2 \\
(1.5 \%\end{array}$ \\
\hline $\begin{array}{l}\text { Total no. of } \\
\text { benign tumours in } \\
\text { study }\end{array}$ & 127 & 131 & 131 \\
\hline
\end{tabular}

In our study fibroadenoma is commonly seen in $2^{\text {nd }}$ and $3^{\text {rd }}$ decades and above-mentioned studies support this fact of our study.

In present study 73 (34.7\%) cases were malignant and finding is similar to the study done by Mayun et al (40\%), while studies done by Sree ND et al $(18.37 \%)$, Pradhan et al $(15.5 \%)$ were not comparable to our study. (12)(13)

In this study most of the malignant lesions occur in $5^{\text {th }}$ and $6^{\text {th }}$ decades, similar to the findings found by Mudholkar et al, Sharma k et al and Gaikwad et al. (14)(15)(16)

In our study most common malignant tumour is invasive ductal carcinoma consist of $70(95 \%$ of 
Dr Geeta Maurya et./al Histopathological spectrum of neoplastic and non-neoplastic breast lesions: A three years study in rural tertiary care center

total malignant cases) in number. Studies of Sree ND et al $(79.41 \%)$, Ayadi et al $(83.8 \%)$ and Raina $\mathrm{V}$ et al (92.8\%). (17) (18)

In our study $3(4.1 \%)$ out of 73 malignant cases were medullary carcinoma, finding is closed to the study of Shanti v et al showed 1 ((3.57\%) case of medullary carcinoma out of 28 malignant cases. Findings in Study of Sree ND et $\mathrm{al}^{6}$ et al were not match with our findings showed $11.76 \%$ of medullary carcinoma. (19)

Table-4- frequency distribution in malignant breast tumours (Comparison with other similar studies)

\begin{tabular}{|l|l|l|l|l|}
\hline $\begin{array}{l}\text { S1 } \\
\text { no }\end{array}$ & $\begin{array}{l}\text { Malignant } \\
\text { tumours }\end{array}$ & $\begin{array}{l}\text { Mudholkar } \\
\text { et al } \\
(2012)\end{array}$ & $\begin{array}{l}\text { Gaikwad } \\
\text { SL et al } \\
(2018)\end{array}$ & $\begin{array}{l}\text { This } \\
\text { study }\end{array}$ \\
\hline 1 & $\begin{array}{l}\text { Invasive } \\
\text { ductal } \\
\text { carcinoma }\end{array}$ & $110(88 \%)$ & $\begin{array}{l}43 \\
(89.5 \%)\end{array}$ & $\begin{array}{l}70 \\
(95.8 \%)\end{array}$ \\
\hline 2 & $\begin{array}{l}\text { Medullary } \\
\text { carcinoma }\end{array}$ & $1(0.75 \%)$ & $\begin{array}{l}2 \\
(4.17 \%)\end{array}$ & $\begin{array}{l}3 \\
(4.1 \%)\end{array}$ \\
\hline $\begin{array}{l}\text { Total no. of } \\
\text { malignant } \\
\text { tumours of } \\
\text { study }\end{array}$ & 48 & 73 \\
\hline
\end{tabular}

Out of 6 non neoplastic lesions acute mastitis was commonest lesion showed 4(2.8\%) cases, another study of Gaikwad et al was not favoring our study showed $6.42 \%$ of cases of acute mastitis.

Other cases in non-neoplastic category were granulomatous mastitis $1(0.4 \%)$ cases fat necrosis $1(0.4 \%)$ case and accessory breast disease 1 $(0.4 \%)$ case, these findings are in favour of findings of Sulhyan et al. (20)

We found Benign epithelial lesion in male was 3 $(1.4 \%)$ cases of gynecomastia which is similar to the study of Gaikwad et al (1.83\%) and Sulhyan et al (2.5\%). (20) (Table-5)
Table-5- Frequency of non-neoplastic breast lesions (Comparison with other similar studies)

\begin{tabular}{|l|l|l|l|l|}
\hline $\begin{array}{l}\text { Sl } \\
\text { n } \\
\text { o }\end{array}$ & $\begin{array}{l}\text { non-neoplastic } \\
\text { breast lesions }\end{array}$ & $\begin{array}{l}\text { Sulhya } \\
\text { n et al } \\
(2017)\end{array}$ & $\begin{array}{l}\text { Gaikwa } \\
\text { d SL et } \\
\text { al } \\
(2018)\end{array}$ & $\begin{array}{l}\text { Presen } \\
\text { t study }\end{array}$ \\
\hline 1 & $\begin{array}{l}\text { Acute/chronic } \\
\text { mastitis }\end{array}$ & $\begin{array}{l}12 \\
(7.45 \% \\
)\end{array}$ & $\begin{array}{l}14 \\
(6.42 \%)\end{array}$ & $\begin{array}{l}4 \\
(1.9 \%)\end{array}$ \\
\hline 2 & $\begin{array}{l}\text { Granulomatou } \\
\text { s mastitis }\end{array}$ & $\begin{array}{l}1 \\
(0.62 \% \\
)\end{array}$ & $2(0.9 \%)$ & $\begin{array}{l}1 \\
(0.4 \%)\end{array}$ \\
\hline 3 & $\begin{array}{l}\text { Fat necrosis } \\
(0.62 \%\end{array}$ & - & $\begin{array}{l}1 \\
(0.4 \%)\end{array}$ \\
\hline 4 & $\begin{array}{l}\text { Fibrocystic } \\
\text { change }\end{array}$ & $\begin{array}{l}6 \\
(3.72 \% \\
)\end{array}$ & $\begin{array}{l}9 \\
(4.13 \%)\end{array}$ & $\begin{array}{l}5 \\
(2.3 \%)\end{array}$ \\
\hline 5 & Gynecomastia & $\begin{array}{l}4 \\
(2.5 \%)\end{array}$ & $\begin{array}{l}4 \\
(1.83 \%)\end{array}$ & $\begin{array}{l}3 \\
(1.4 \%)\end{array}$ \\
\hline \multicolumn{2}{|l|}{$\begin{array}{l}\text { Total no of cases in } \\
\text { study }\end{array}$} & 161 & 218 & 210 \\
\hline
\end{tabular}

\section{Conclusion:}

We found non-neoplastic lesions less commonly than neoplastic lesions in our study. Fibroadenoma was the commonest breast lesion followed by invasive ductal carcinoma and then acute mastitis. Large number of cases of invasive ductal carcinoma ( $>33 \%$ of all cases) were seen in our study, which is a serious concern. So generation of awareness among women is need of time to reduce the morbidity and mortality specially in Indian rural setup. Benign tumours were mostly seen in $2^{\text {nd }}$ and $3^{\text {rd }}$ decade and malignant tumour mainly in $5^{\text {th }}$ and $6^{\text {th }}$ decade. But now malignant cases were also seen in young age groups, so early diagnosis of any breast lesion is very necessary for adequate and correct treatment of patient.

\section{References-}

1. Aziz Z, Sana S, Saeed S, Akram M. institution-based tumor registry from Punjab: five-year data-based analysis. J Pakistan Med Assoc. 2003 Aug;53(8):3503

2. Naveen N, Mukherjee A, Mahajan V. A clinical study of benign breast disease in 
rural population. J Evol Med Dent Sci. 2013;2(30):5499-511

3. Qin X, Peng Q, Qin A, Chen Z, Lin L, Deng $Y$, et al. Association of COMT Val158Met polymorphism and breast cancer risk: an updated meta-analysis. Diag Pathol. 2012 Dec;7(1):136.

4. Khanna R, Khanna S, Chaturvedi S, Arya NC. Spectrum of breast disease in young females: A retrospective study of 1315 patients. Indian $\mathrm{J}$ Pathol Microbiol. 1998;41(4):397-401.

5. Pai $\mathrm{S}$. the spectrum of benign breast diseases among females: A6-year histopathological study. Indian journal of Pathology and Oncology. 2019;6(4):561567

6. Sree ND et al. clinicopathological study of breast lesions over a period of one year in a tertiary care center. Int J Res Med Sci. 2018 Oct;6(10):3397-3402.

7. Kumar M, Ray K, Harode S, Wagh DD. The pattern of benign breast diseases in rural hospital in India. East central African J Surg. 2010;15(2):59-64.

8. Oluwole SF, Freeman HP. Analysis of benign breast lesions in blacks. Am J Surg. 1979;137:786-789.

9. Amr SS, Sa'di AR, Ilahi F, Sheikh SS. The spectrum of breast diseases in Saudi Arab females: a 26-year pathological survey at Dhahran Health Center. Ann Saudi Med. 1995 Mar 1:15(2):125-32.

10. Sangeeta K, Vora Ila M, Kanchanmala G, Shanu S. Histopathological spectrum of breast lesions with reference to uncommon cases. Tuberculosis. 2009 Sep;2:1-45.

11. Malik M, Salahuddin O, Azhar M, Dilawar O, Irshad H, Sadia SA. Breast diseases; spectrum in wah cantt; POF hospital experience. Professional Med J. 2010 Sep;17(3):366-72.
12. Mayun AA, Pindiga UH, babayo UD. Pattern of histopathological diagnosis of breast lesions in Gombe, Nigeria. Nigerian J Med. 2008;17(2)15962.

13. Pradhan M, Dhakal HP. Study of breast lump of 2246 cases by fine needle aspiration. J Nepal Medi Assoc. 2008 Oct $1 ; 47(172)$.

14. Mudholkar VG, Kawade SB, Mashal SN. Histopathological study of neoplastic lesions of breast. Ind Med Gazette. 2012:35364.

15. Sharma K, Vyas SP, Dhayal SI. Clinical and histopathological correlation of breast lesions. Int J Res Med Sci. 2018 Apr;6(4):1348-1355.

16. Gaikwad SL et al. A histopathological study of neoplastic and non neoplastic breast lesions. Medpulse- international medical journal. 2019 Jan; vol 9: issue 1.

17. Ayadi L, khabir A, Amouri H, Karray S, Dammak A, Guermazi M, et al. correlation of HER-2 overexpression with clinicpathological parameters in Tunisian breast carcinoma. World J Surg Oncol. 2008 Dec;6(1):112.

18. Lokuhetty MD, Ranaweera GG, Wijeratne MD, Wickramasinghe KH, Sheriffdeen AH. Profile of breast cancer in a group of women in a developing country in South Asia: is there a difference?. World J Surg. 2009 Mar 1;33(3):455-9.

19. Shanthi V, Ali K, Rao NM, Krishna BR, Muralimohan KV. Clinicopathological study of breast lesions in females with assessment of correlation between tumor grade and prognostic factors and NBSP. J Biosci Tech. 2001;2(5):367-8.

20. Sulhyan KR, Anvikar AR, Mujawar IM, Tiwari H. Histopathological study of breast lesions. International J Med research and review. 2017: vol 5, No 1 .. 